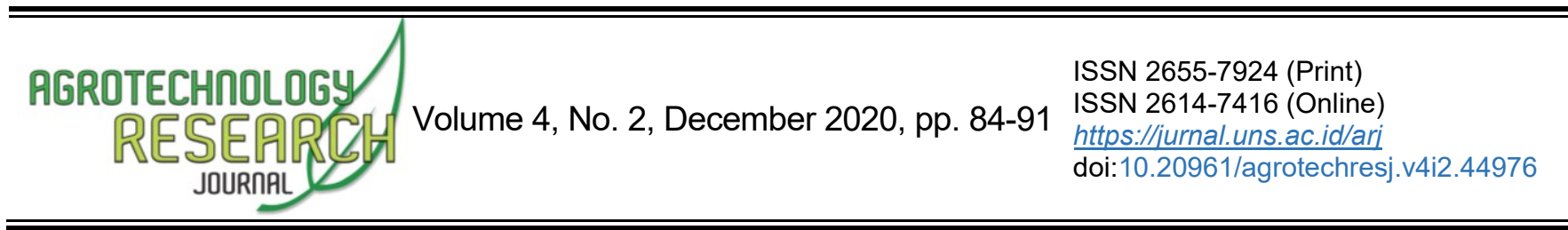

\title{
Skrining dan Efektivitas Metabolit Sekunder Mikania micrantha pada Gulma Jajagoan serta Dampaknya terhadap Padi Sawah
}

\author{
Alridiwirsah ${ }^{1}$, Koko Tampubolon ${ }^{2}$, Fransisca Natalia Sihombing ${ }^{3}$, Wan Arfiani Barus ${ }^{4}$, Irna Syofia ${ }^{5}$, Tengku \\ Boumedine Hamid Zulkifli ${ }^{6}$, Zavandri Purba ${ }^{7}$ \\ ${ }^{1,4,5}$ Program Study of Agrotechnology, Faculty of Agriculture, Universitas Muhammadiyah Sumatera Utara, Medan 20238, \\ Sumatera Utara, Indonesia \\ ${ }^{2,6}$ Program Study of Agrotechnology, Faculty of Agriculture and Animal Husbandry, Universitas Tjut Nyak Dhien, Medan 20123, \\ Sumatera Utara, Indonesia \\ ${ }^{3}$ Program Magister of Agribusiness, Faculty of Agriculture, Universitas Sumatera Utara, Medan 20155, Sumatera Utara, Indonesia \\ ${ }^{7}$ Program Study of Agrotechnology, Faculty of Agriculture, Universitas Sumatera Utara, Medan 20155, Sumatera Utara, Indonesia
}

Received 18 October 2020; Accepted 04 November 2020; Published 1 December 2020

\section{ABSTRACT}

Secondary metabolites from Mikania micrantha could be expected to control barnyardgrass (Echinochloa crus-galli) characteristics and have an effect on lowland rice. This research was aimed to screening of secondary metabolites in M. micrantha extract, obtaining the greater extract concentration in suppressing the barnyardgrass growth, and determine the impact on the lowland rice characteristics. This method used was Randomized Completely Block Design in non-factorial within the concentration rates of $M$. micrantha extract using ethanol $96 \%(0 \% ; 20 \% ; 40 \%$; $60 \% ; 80 \% ; 100 \%$, and herbicide 2,4-D dimethylamine at the dose of $1 \mathrm{I} \mathrm{ha}^{-1}$ as a comparison). Lowland rice and barnyardgrass characteristics were analyzed using F-test and followed by DMRT at $5 \%$ with SPSS software. The result showed that $M$. micrantha had secondary metabolites include alkaloids, flavonoids, and tannins. The concentration at 20 to $100 \%$ significantly decreased the fresh- and dry-weight of barnyardgrass with the highest suppressing found in $60 \%$ concentration by $65.91 \%$ and $67.92 \%$, respectively compared to un-sprayed. The concentrations at $20 \%$ and $60 \%$ were classified as inhibiting the growth biomass of barnyardgrass. The concentrations at $20 \%, 60 \%$, and $80 \%$ can still encourage the tillers growth of lowland rice. An extract concentration of M. micrantha at $20 \%$ can be applied to inhibit the growth of barnyardgrass biomass and stimulate the lowland rice tillers.

Keywords: Allelopathy response index; Concentration; Natural herbicide; Weed control

Cite This As (CSE Style): Alridiwirsah, Tampubolon K, Sihombing FN, Barus WA, Syofia I, Zulkifli TBH, Purba Z. 2020. Skrining dan Efektivitas Metabolit Sekunder Mikania micrantha pada Gulma Jajagoan serta Dampaknya terhadap Padi Sawah. Agrotech Res J. 4(2): 84-91. https://doi.org/10.20961/agrotechresj.v4i2.44976

\section{PENDAHULUAN}

Kehadiran gulma Jajagoan (Echinochloa crus-galli L. Beauv) pada areal pertanaman mengakibatkan kerugian kualitatif dan kuantitatif produktivitas padi sawah yang disebabkan adanya persaingan unsur hara, air, dan intensitas cahaya matahari. Telah dilaporkan Wilson et al. (2014) bahwa keberadaan satu populasi E. crus-galli pada jarak $40 \mathrm{~cm}$ dari tanaman padi sawah dapat mengurangi hasil panen sebesar $27 \%$ dan dapat menyerap ketersediaan nitrogen sebesar $60-80 \%$. Saito et al. (2010) melaporkan gulma E. crus-galli dapat menyebabkan penurunan hasil gabah padi mencapai $61 \%$. Guntoro et al. (2009) melaporkan bahwa E. crusgalli dapat menurunkan jumlah daun, jumlah anakan

${ }^{*}$ Corresponding Author:

E-Mail: koko.tampubolon@gmail.com produktif, bobot kering akar, panjang daun, luas daun bendera, dan produksi tanaman padi sawah. Usman et al. (2016) melaporkan gulma E. crus-galli menghambat tinggi tanaman, menurunkan jumlah anakan produktif, jumlah gabah isi/malai, bobot kering tajuk dan bobot gabah/rumpun tanaman padi sawah. Gibson et al. (2002); Clay et al. (2005) melaporkan E. crus-galli dapat menghasilkan biji dalam jumlah banyak dan memiliki tingkat dormansi biji yang meningkatkan seedbank di dalam tanah. Travlos et al. (2011) juga melaporkan kerapatan 10 gulma E. crus-galli per $\mathrm{m}^{2}$ dapat menghasilkan 34.600 biji. Marambe dan Amarasinghe (2002) juga melaporkan gulma ini memiliki kemampuan kompetitif dan karakteristik adaptif untuk bertahan hidup pada berbagai kondisi iklim dan geografis.

Pengendalian gulma pada areal pertanaman dengan herbisida sintesis yang berlebihan akan berdampak pada kerusakan ekosistem dan produksi tanaman. Umiyati (2019) melaporkan bahwa penyemprotan 
herbisida parakuat diklorida 1,5 I/ha + tanpa olah tanah merupakan dosis yang paling baik mengendalikan gulma pada pertanaman jagung, namun dapat menurunkan hasil/petak tanaman jagung sebesar 12,96\% dibandingkan kontrol. Dengan demikian diperlukan alternatif pengendalian gulma $E$. crus-galli yang bersahabat dengan lingkungan, salah satunya menggunakan pemanfaatan sumber daya alam yang tersedia di lapangan sebagai herbisida nabati. Penelitian terdahulu melaporkan bahwa gulma memiliki senyawa alelopati yang dapat menekan pertumbuhan gulma sasaran. Tampubolon et al. (2018) melaporkan bahwa gulma dapat dijadikan herbisida nabati yang bahan aktifnya banyak tersedia dari lahan pertanian. Junaedi et al. (2006) melaporkan bahwa senyawa metabolit sekunder pada gulma seperti fenolik, terpenoid, tanin, alkaloid, steroid, minyak esensial, dan poliasetilena memiliki aktivitas alelopati.

Gulma Mikania micrantha telah dilaporkan mampu berperan sebagai herbisida nabati. Pebriani et al. (2013) melaporkan ekstrak daun sembung rambat ( $M$. micrantha) pada konsentrasi $15 \%$ dapat menghambat persentase perkecambahan, panjang kecambah dan tinggi gulma, sedangkan konsentrasi $7,5 \%$ dapat menghambat bobot segar dan bobot kering gulma Cleome rutidosperma. Pérez-Amador et al. (2010) menyatakan bahwa gulma sembung rambat memiliki senyawa alelokimia berupa fenol, flavonoid dan terpenoid. Kristanto (2006) melaporkan bahwa senyawa alelokimia seperti fenol dan flavonoid lebih efektif menghambat aktivitas enzim selama proses perkecambahan.

Hasil penelitian sebelumnya telah membuktikan bahwa ekstrak gulma dapat menghambat pertumbuhan gulma sasaran, namun belum pernah dilaporkan penggunaan konsentrasi ekstrak etanol gulma $M$. micrantha yang berpotensi menekan pertumbuhan gulma Jajagoan melalui indeks respons alelopati dari setiap konsentrasi ekstrak dan bagaimana pengaruhnya terhadap karakter pertumbuhan padi sawah. Tujuan penelitian ini antara lain: (1) menskrining metabolit sekunder yang terdapat pada ekstrak gulma $M$. micrantha, (2) mendapatkan konsentrasi ekstrak yang tepat dalam menekan pertumbuhan gulma Jajagoan $(E$. crus-galli) dan (3) mengetahui dampaknya terhadap karakteristik padi sawah.

\section{BAHAN DAN METODE \\ Lokasi dan metode penelitian}

Penelitian dilaksanakan di Jl. Abdul Hakim, Padang Bulan, Medan pada Juni - September 2020. Skrining metabolit sekunder gulma $M$. micrantha dilakukan di Laboratorium Kimia Organik, Fakultas MIPA Universitas Sumatera Utara. Penelitian ini menggunakan Rancangan Acak Kelompok Lengkap (RAKL) nonfaktorial dengan faktor konsentrasi ekstrak gulma $M$. micrantha $\left(\mathrm{MM}_{0}=0 \%, \mathrm{MM}_{1}=20 \%, \mathrm{MM}_{2}=40 \%, \mathrm{MM}_{3}=\right.$ $60 \%, \mathrm{MM}_{4}=80 \%, \mathrm{MM}_{5}=100 \%$, dan $\mathrm{MM}_{6}=$ herbisida $2,4-$ D dimetil amina (herbisida U-46) pada dosis rekomendasi $1 \mathrm{l} /$ ha sebagai pembanding.

\section{Modifikasi media tanam}

Disiapkan media tanam untuk ember dengan mencampurkan topsoil, pupuk kandang ayam, dan pasir $(1: 1: 1)$ kemudian digenangi air selama 6 minggu sampai kondisi media seperti tanah sawah.

\section{Koleksi biji gulma jajagoan dan benih padi sawah}

Biji gulma jajagoan diambil dari lahan petani pertanaman padi sawah di Padang Bulan, Medan. Benih padi sawah irigasi yang digunakan adalah varietas Inpari 32 diambil dari UPT. Balai Pengawasan dan Sertifikasi Benih Provinsi Sumatera Utara.

\section{Pengecambahan gulma jajagoan dan padi sawah}

Media tanam untuk perkecambahan benih padi sawah dan gulma jajagoan diambil dari ember kemudian dimasukkan ke bak kecambah. Ditabur 20 biji padi sawah dan gulma pada masing-masing bak kecambah kemudian dipelihara selama 4 minggu setelah tabur. Dilakukan penyiraman setiap hari.

\section{Transplanting benih padi sawah dan gulma jajagoan}

Benih padi sawah setelah memiliki tinggi $15 \mathrm{~cm}$ dipindah tanam ke media ember sebanyak satu benih/ember dengan posisi penanaman tepat ditengah diameter ember. Benih gulma jajagoan dipindah tanam setelah berdaun 3-4 helai ke media ember sebanyak 5 benih/ember dengan posisi mengelilingi padi sawah.

\section{Pemupukan dasar}

Pemupukan dasar dilakukan pada saat 1 minggu setelah transplanting benih padi sawah dengan pupuk NPK Mutiara 16-16-16 dosis 4,06 g/ember yang ditabur merata.

\section{Pembuatan dan skrining metabolit sekunder gulma Mikania micrantha}

Gulma M. micrantha diambil dari lahan percobaan Fakultas Pertanian, Universitas Sumatera Utara, Medan sebanyak $2.367 \mathrm{~g}$. Pengestrak yang digunakan dalam pembuatan sebagai herbisida nabati adalah etanol $96 \%$ dengan massa jenis $(\rho)=0,789 \mathrm{~g} / \mathrm{cm}^{3}$. Jumlah ekstrak yang digunakan setiap perlakuan yang digunakan sebanyak 1 liter. Setiap perlakuan diberikan penambahan adjuvat agristik $400 \mathrm{~g} / \mathrm{l}$ (Dadang dan Prijono 2011) dengan konsentrasi $2 \%$ (20 ml/l) dalam menjaga kestabilan formulasi herbisida nabati.

Skrining metabolit sekunder gulma M. micrantha menggunakan metode kualitatif dengan mengambil 10 $\mathrm{ml}$ ekstrak dan dianalisis kandungan alkaloid, tanin, flavonoid, steroid dan triterpenoid. Pengukuran metabolit sekunder alkaloid dilakukan dengan memasukkan $2 \mathrm{ml}$ ke tabung reaksi kemudian ditambahkan 2 tetes pereaksi Bouchardat dan ditunggu selama 1 menit, jika positif sampel berubah warna menjadi endapan cokelat. Pengukuran metabolit sekunder flavonoid dilakukan dengan memasukkan $2 \mathrm{ml}$ ke tabung reaksi kemudian ditambahkan 2 tetes pereaksi $\mathrm{FeCl}_{3} 5 \%$ dan ditunggu selama 1 menit, jika positif sampel berubah warna menjadi koloid hitam. Pengukuran metabolit sekunder steroid dan triterpenoid dilakukan dengan memasukkan $2 \mathrm{ml}$ ke tabung reaksi kemudian ditambahkan 2 tetes pereaksi Liebermann-Burchard dan ditunggu selama 1 menit, jika positif sampel berubah warna menjadi cincin perak. Pengukuran metabolit sekunder tanin dilakukan 
dengan memasukkan $2 \mathrm{ml}$ ke tabung reaksi kemudian ditambahkan 2 tetes pereaksi $\mathrm{FeCl}_{3} 1 \%$ dan ditunggu selama 1 menit, jika positif sampel berubah warna menjadi koloid hitam.

\section{Aplikasi metabolit sekunder gulma Mikania micrantha}

Aplikasi konsentrasi ekstrak M. micrantha dilakukan saat gulma jajagoan berdaun 10-12 helai sesuai dengan masing-masing perlakuan. Dilakukan terlebih dahulu kalibrasi penyemprotan untuk herbisida pembanding (herbisida 2,4-D dimetil amina).

\section{Pemeliharaan tanaman padi sawah dan gulma jajagoan}

Pemeliharaan tanaman padi dilakukan sampai akhir pengamatan seperti penyemprotan insektisida Decis 25 EC untuk mengendalikan hama padi, fungisida Antracol 70 WP untuk mengendalikan penyakit padi berdasarkan dosis rekomendasi.

\section{Parameter dan analisis data}

Karakteristik padi sawah. Terlebih dahulu diambil parameter tinggi tanaman dan jumlah anakan tanaman padi sawah sebelum diaplikasikan herbisida nabati. Pengamatan padi sawah dilakukan sampai masa vegetatif seperti tinggi tanaman dan jumlah anakan pada 1-2 Minggu Setelah Semprot (MSS), bobot segar tanaman, dan bobot kering tanaman pada akhir pengamatan (2 MSS). Pengukuran bobot segar total padi sawah dilakukan dengan membersihkan akar padi dari tanah kemudian dikeringanginkan selama 2 jam dan ditimbang dengan timbangan analitik. Pengukuran bobot kering padi sawah dengan mengovenkan pada suhu $65^{\circ} \mathrm{C}$ selama 72 jam (Jalaludin et al. 2015).

Karakteristik gulma jajagoan. Terlebih dahulu diambil parameter jumlah anakan gulma jajagoan sebelum diaplikasikan herbisida nabati. Pengamatan gulma jajagoan antara lain jumlah anakan gulma pada 1 2 MSS, bobot segar total, bobot kering total pada akhir pengamatan (2 MSS), dan indeks respons alelopati. Pengukuran bobot segar jajagoan dilakukan dengan membersihkan akar jajagoan dari tanah kemudian dikeringaginkan selama 2 jam kemudian ditimbang dengan timbangan analitik. Pengukuran bobot kering jajagoan dengan mengovenkan pada suhu $65^{\circ} \mathrm{C}$ selama 72 jam (Jalaludin et al. 2015). Pengukuran Indeks Respons Alelopati (IRA) berdasarkan bobot kering gulma total menggunakan rumus Williamson dan Richardson (1988):

$$
\mathrm{IRA}=\frac{\text { Bobot kering gulma total (kontrol) }}{\text { Bobot kering gulma total (perlakuan) }}-1
$$

Jika nilai IRA > 0, maka efek alelopati bersifat stimulasi, namun jika nilai IRA $<0$, maka efek alelopati bersifat penghambat. Nilai indeks respons alelopati terletak -1 < IRA > 1 (Sunmonu dan Van Staden 2014). Data karakteristik padi sawah dan gulma jajagoan dianalisis menggunakan ANOVA dan dilanjutkan dengan uji DMRT taraf $5 \%$ menggunakan software IBM SPSS Statistics v.20.

\section{HASIL DAN PEMBAHASAN}

\section{Skrining kualitatif metabolit sekunder gulma Mikania micrantha}

Hasil skrining metabolit sekunder gulma M. micrantha dapat dilihat pada Tabel 1.

Tabel 1. Skrining metabolit sekunder gulma $M$. micrantha

\begin{tabular}{llc}
\hline Senyawa & Pereaksi & $\begin{array}{c}\text { Uji } \\
\text { Kualitatif }\end{array}$ \\
\hline Alkaloid & Bouchardat & + \\
Flavonoid & $\mathrm{FeCl}_{3} 5 \%$ & + \\
Steroid dan Triterpenoid & $\mathrm{Liebermann}^{5}$ & - \\
& $\mathrm{Burchard}^{2}$ & \\
Tanin & $\mathrm{FeCl}_{3} 1 \%$ & + \\
\hline
\end{tabular}

Keterangan: (+) menyatakan terdeteksi; (-) menyatakan tidak terdeteksi.

Hasil skrining secara kualitatif menunjukkan bahwa ekstrak gulma M. micrantha memiliki senyawa alkaloid, flavonoid, dan tanin, namun tidak memiliki senyawa steroid dan triterpenoid. Hasil skrining metabolit sekunder ini didukung penelitian Wei et al. (2004) melaporkan bahwa $M$. micrantha memiliki fitokimia flavonoid. Zhang et al. (2003) melaporkan bahwa $M$. micrantha memiliki fitokimia alkaloid. Perawati et al. (2018) melaporkan M. micrantha dengan ekstrak $70 \%$ etanol memiliki senyawa alkaloid, flavonoid, saponin, polifenol, dan steroid. Fernandes et al. (2018) melaporkan daun $M$. micrantha memiliki senyawa alkaloid, steroid dan triterpenoid. Latha et al. (2015) juga melaporkan bahwa $M$. micrantha memiliki senyawa glikosid, terpenoid, fenolik, alkaloid, steroid, flavonoid, dan tanin.

\section{Karakteristik tanaman padi sawah}

Hasil ANOVA pengaruh konsentrasi ekstrak $M$. micrantha dan herbisida pembanding terhadap karakteristik tanaman padi sawah dapat dilihat pada Tabel 2-4 dan Gambar 1. Konsentrasi ekstrak $M$. micrantha dan herbisida 2,4-D dimetil amina 1 I/ha berpengaruh tidak nyata terhadap tinggi tanaman padi sawah umur 1-2 MSS (Tabel 2). Pertumbuhan tinggi tanaman padi sawah pada konsentrasi ekstrak $M$. micrantha dan herbisida 2,4-D dimetil amina $1 \mathrm{l} /$ ha lebih pendek dibandingkan kontrol. Konsentrasi $100 \%$ ekstrak $M$. micrantha dapat menghambat pertumbuhan tinggi tanaman padi sawah tertinggi diantara konsentrasi ekstrak lainnya dan memiliki hambatan 15,11\% dibandingkan kontrol, sedangkan efek herbisida 2,4-D dimetil amina $1 \mathrm{l} /$ ha dapat menghambat pertumbuhan tinggi tanaman padi sawah sebesar 16,10\% dibandingkan kontrol.

Konsentrasi ekstrak M. micrantha dan herbisida pembanding signifikan meningkatkan jumlah anakan tanaman padi sawah umur 2 MSS, namun berpengaruh tidak nyata terhadap jumlah anakan 1 MSS (Tabel 3). Pertumbuhan jumlah anakan tanaman padi sawah tertinggi terdapat pada konsentrasi $60 \%$ ekstrak $M$. micrantha dan berbeda nyata dibandingkan konsentrasi ekstrak lainnya dan herbisida 2,4-D dimetil amina $1 \mathrm{l} / \mathrm{ha}$ pada umur 2 MSS. Konsentrasi $20-100 \%$ ekstrak $M$. micrantha dapat meningkatkan jumlah anakan tanaman padi sawah dibandingkan kontrol dan herbisida 2,4-D dimetil amina $1 \mathrm{l} / \mathrm{ha}$ pada umur 2 MSS. Konsentrasi $60 \%$ ekstrak M. micrantha dapat meningkatkan jumlah anakan tanaman padi sawah tertinggi sebesar $57,23 \%$ dibandingkan kontrol. 
Hubungan konsentrasi ekstrak $M$. micrantha terhadap jumlah anakan tanaman padi sawah umur 2 MSS (Gambar 1).

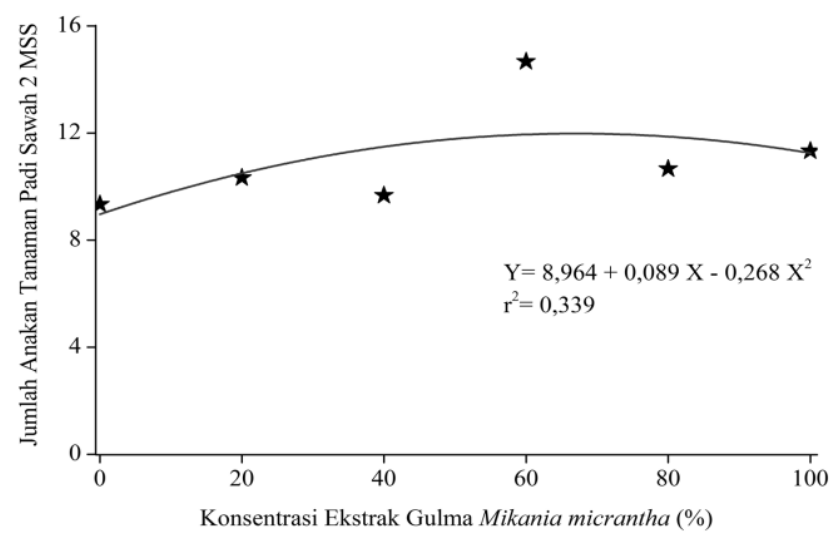

Gambar 1. Hubungan konsentrasi ekstrak M. micrantha terhadap jumlah anakan tanaman padi sawah umur 2 MSS
Konsentrasi ekstrak M. micrantha memiliki hubungan kuadratik terhadap jumlah anakan tanaman padi sawah umur 2 MSS dengan persamaan regresi $Y=8,964+$ $0,089 X-0,268 X^{2}$ dan nilai koefisien 0,339 . Hal ini menunjukkan bahwa konsentrasi ekstrak $M$. micrantha berpengaruh sebesar $33,90 \%$ terhadap jumlah anakan tanaman padi sawah umur 2 MSS.

Konsentrasi ekstrak $M$. micrantha dan herbisida pembanding berpengaruh tidak nyata terhadap bobot segar total dan bobot kering total tanaman padi sawah (Tabel 4). Ekstrak M. micrantha dengan konsentrasi 20, 60 , dan $80 \%$ menunjukkan bobot segar total tanaman padi sawah lebih tinggi dibandingkan kontrol dan herbisida 2,4-D dimetil amina $1 \mathrm{l} / \mathrm{ha}$. Bobot segar total tanaman padi sawah tertinggi terdapat pada konsentrasi $20 \%$ ekstrak M. micrantha. Pengaruh konsentrasi $80 \%$ ekstrak $M$. micrantha menunjukkan bobot kering tanaman padi sawah lebih tinggi sebesar $0,63 \%$ dibandingkan kontrol dan $142,72 \%$ dibandingkan herbisida 2,4-D dimetil amina 1 l/ha.

Tabel 2. Pengaruh konsentrasi ekstrak $M$. micrantha dan herbisida pembanding terhadap pertumbuhan tinggi tanaman padi sawah umur 1-2 MSS

\begin{tabular}{lccc}
\hline \multirow{2}{*}{ Tabel Perlakuan } & \multicolumn{3}{c}{ Tinggi Tanaman Padi Sawah (cm) } \\
\cline { 2 - 4 } & Sebelum Semprot & 1 MSS & MSS \\
\hline Konsentrasi Ekstrak 0\% & $41,63 \pm 1,39$ & $49,20 \pm 0,61 \mathrm{tn}$ & $53,40 \pm 1,40 \mathrm{tn}$ \\
Konsentrasi Ekstrak 20\% & $45,83 \pm 0,84$ & $50,33 \pm 1,26 \mathrm{tn}$ & $51,70 \pm 1,37 \mathrm{tn}$ \\
Konsentrasi Ekstrak 40\% & $45,83 \pm 1,21$ & $49,00 \pm 1,25 \mathrm{tn}$ & $50,43 \pm 1,16 \mathrm{tn}$ \\
Konsentrasi Ekstrak 60\% & $44,00 \pm 1,13$ & $45,97 \pm 1,11 \mathrm{tn}$ & $47,13 \pm 1,10 \mathrm{tn}$ \\
Konsentrasi Ekstrak 80\% & $44,27 \pm 1,11$ & $49,63 \pm 1,29 \mathrm{tn}$ & $51,50 \pm 1,34 \mathrm{tn}$ \\
Konsentrasi Ekstrak 100\% & $41,83 \pm 0,62$ & $44,23 \pm 0,82 \mathrm{tn}$ & $45,33 \pm 0,94 \mathrm{tn}$ \\
Herbisida 2,4-D Dimetil Amina & $42,07 \pm 0,73$ & $43,47 \pm 0,70$ tn & $44,80 \pm 0,76 \mathrm{tn}$ \\
\hline
\end{tabular}

Keterangan: Data yang diikuti oleh huruf yang berbeda pada baris yang sama menunjukkan berbeda nyata berdasarkan uji DMRT $5 \% \pm$ Standar Error (SE).

Tabel 3. Pengaruh konsentrasi ekstrak M. micrantha dan herbisida pembanding terhadap jumlah anakan tanaman padi sawah umur 1-2 MSS

\begin{tabular}{lccc}
\hline \multirow{2}{*}{ Perlakuan } & \multicolumn{2}{c}{ Jumlah Anakan Tanaman Padi Sawah } \\
\cline { 2 - 4 } & Sebelum Semprot & $1 \mathrm{MSS}$ & MSS \\
\hline Konsentrasi Ekstrak 0\% & $7,00 \pm 0,82$ & $8,67 \pm 0,71 \mathrm{tn}$ & $9,33 \pm 0,71 \mathrm{~b}$ \\
Konsentrasi Ekstrak 20\% & $9,00 \pm 0,94$ & $9,67 \pm 1,08 \mathrm{tn}$ & $10,33 \pm 1,12 \mathrm{~b}$ \\
Konsentrasi Ekstrak 40\% & $8,00 \pm 0,76$ & $8,33 \pm 0,62 \mathrm{tn}$ & $9,67 \pm 0,62 \mathrm{~b}$ \\
Konsentrasi Ekstrak 60\% & $11,00 \pm 0,82$ & $12,33 \pm 0,71 \mathrm{tn}$ & $14,67 \pm 0,83 \mathrm{a}$ \\
Konsentrasi Ekstrak 80\% & $9,33 \pm 0,62$ & $10,67 \pm 0,62 \mathrm{tn}$ & $10,67 \pm 0,62 \mathrm{~b}$ \\
Konsentrasi Ekstrak 100\% & $9,00 \pm 0,76$ & $10,33 \pm 0,62 \mathrm{tn}$ & $11,33 \pm 0,44 \mathrm{ab}$ \\
Herbisida 2,4-D Dimetil Amina & $7,00 \pm 0,76$ & $8,67 \pm 0,83 \mathrm{tn}$ & $9,00 \pm 0,76 \mathrm{~b}$ \\
\hline
\end{tabular}

Keterangan: Data yang diikuti oleh huruf yang berbeda pada baris yang sama menunjukkan berbeda nyata berdasarkan uji DMRT $5 \% \pm$ SE.

Tabel 4. Pengaruh konsentrasi ekstrak $M$. micrantha dan herbisida pembanding terhadap bobot segar total dan bobot kering total tanaman padi sawah

\begin{tabular}{lcc}
\hline \multirow{2}{*}{ Perlakuan } & \multicolumn{2}{c}{ Biomassa Tanaman Padi Sawah } \\
\cline { 2 - 3 } & Bobot Segar Total $(\mathrm{g})$ & Bobot Kering Total $(\mathrm{g})$ \\
\hline Konsentrasi Ekstrak 0\% & $31,88 \pm 1,69 \mathrm{tn}$ & $12,76 \pm 1,36 \mathrm{tn}$ \\
Konsentrasi Ekstrak 20\% & $39,59 \pm 2,57 \mathrm{tn}$ & $12,47 \pm 1,37 \mathrm{tn}$ \\
Konsentrasi Ekstrak 40\% & $24,96 \pm 0,93 \mathrm{tn}$ & $8,62 \pm 0,96 \mathrm{tn}$ \\
Konsentrasi Ekstrak 60\% & $37,44 \pm 1,55 \mathrm{tn}$ & $12,58 \pm 1,30 \mathrm{tn}$ \\
Konsentrasi Ekstrak 80\% & $33,25 \pm 2,46 \mathrm{tn}$ & $12,84 \pm 1,41 \mathrm{tn}$ \\
Konsentrasi Ekstrak 100\% & $29,49 \pm 1,21 \mathrm{tn}$ & $10,72 \pm 0,98 \mathrm{tn}$ \\
Herbisida 2,4-D Dimetil Amina & $18,30 \pm 2,20 \mathrm{tn}$ & $5,29 \pm 0,87 \mathrm{tn}$ \\
\hline
\end{tabular}

Keterangan: Data yang diikuti oleh huruf yang berbeda pada baris yang sama menunjukkan berbeda nyata berdasarkan uji DMRT $5 \% \pm$ SE. 


\section{Karakteristik gulma jajagoan}

Hasil ANOVA pengaruh konsentrasi ekstrak $M$. micrantha dan herbisida pembanding terhadap karakteristik gulma jajagoan dapat dilihat Tabel 5 dan Gambar 2-5. Konsentrasi ekstrak $M$. micrantha dan herbisida 2,4-D dimetil amina 1 l/ha signifikan mengendalikan jumlah anakan gulma jajagoan pada 2 MSS, namun berpengaruh tidak nyata pada 1 MSS (Tabel 5). Jumlah anakan gulma jajagoan mengalami peningkatan pada semua konsentrasi ekstrak sebelum semprot sampai 1 MSS dan peningkatan ini berlangsung sampai 2 MSS kecuali pada konsentrasi 100\% ekstrak $M$. micrantha. Jumlah anakan gulma jajagoan mengalami penurunan pada perlakuan herbisida 2,4-D dimetil amina $1 \mathrm{l} /$ ha sebelum semprot sampai $2 \mathrm{MSS}$. Ekstrak M. micrantha dengan konsentrasi $20 \%$ dan $100 \%$, serta herbisida 2,4-D dimetil amina 1 l/ha signifikan mengendalikan jumlah anakan gulma jajagoan masing-masing sebesar $27,41 \%$; $36,29 \%$; dan $36,96 \%$ dibandingkan kontrol serta berbeda nyata dengan konsentrasi ekstrak lainnya pada 2 MSS.

Hubungan konsentrasi ekstrak $M$. micrantha terhadap jumlah anakan gulma jajagoan umur 2 MSS (Gambar 2). Konsentrasi ekstrak M. micrantha memiliki hubungan kuadratik terhadap jumlah anakan gulma jajagoan pada 2 MSS dengan persamaan regresi $Y=$ $10,060-0,451 X+0,003 X^{2}$ dan nilai koefisien 0,758 . Hal ini menunjukkan bahwa konsentrasi ekstrak $M$. micrantha berpengaruh sebesar $75,80 \%$ terhadap jumlah anakan gulma jajagoan pada 2 MSS.

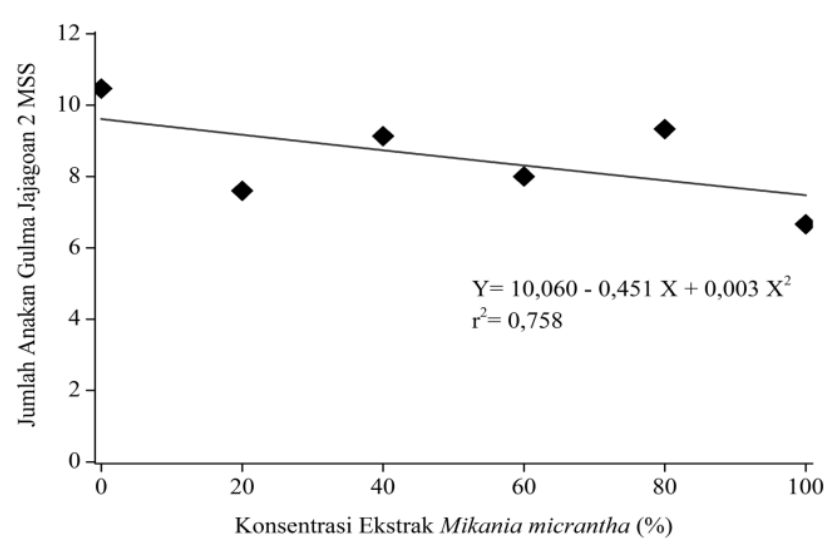

Gambar 2. Hubungan konsentrasi ekstrak M. micrantha terhadap jumlah anakan gulma jajagoan umur 2 MSS
Konsentrasi ekstrak M. micrantha dan herbisida pembanding signifikan mengendalikan bobot segar total gulma jajagoan (Gambar 3).

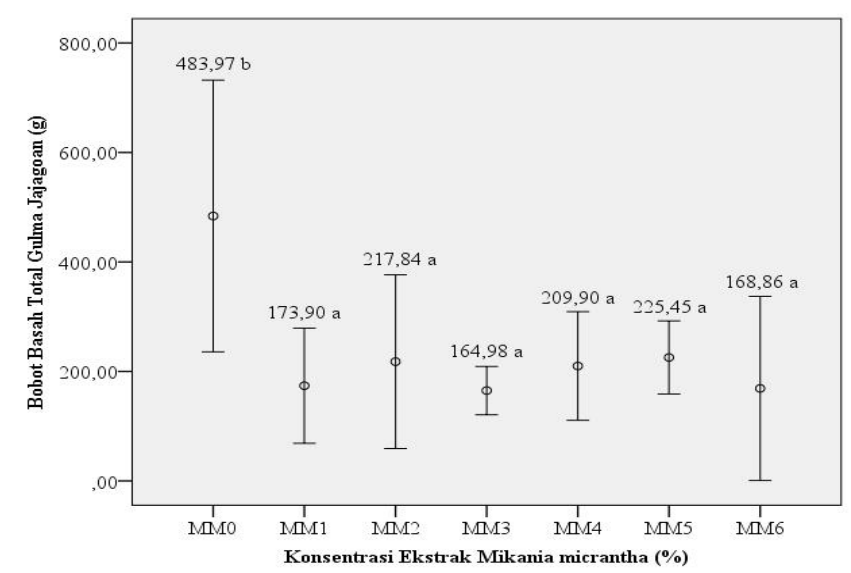

Gambar 3. Pengaruh konsentrasi ekstrak $M$. micrantha dan herbisida pembanding terhadap bobot segar total gulma jajagoan \pm SE. Konsentrasi ekstrak $(M M 0=0 \%, M M 1=20 \%$, MM2 $=40 \%$, MM3 $=60 \%$, MM4 $=80 \%$, MM5 $=100 \%$, dan MM6= herbisida 2,4-D dimetil amina)

Konsentrasi ekstrak M. micrantha dan herbisida pembanding signifikan mengendalikan bobot kering total gulma jajagoan (Gambar 4).

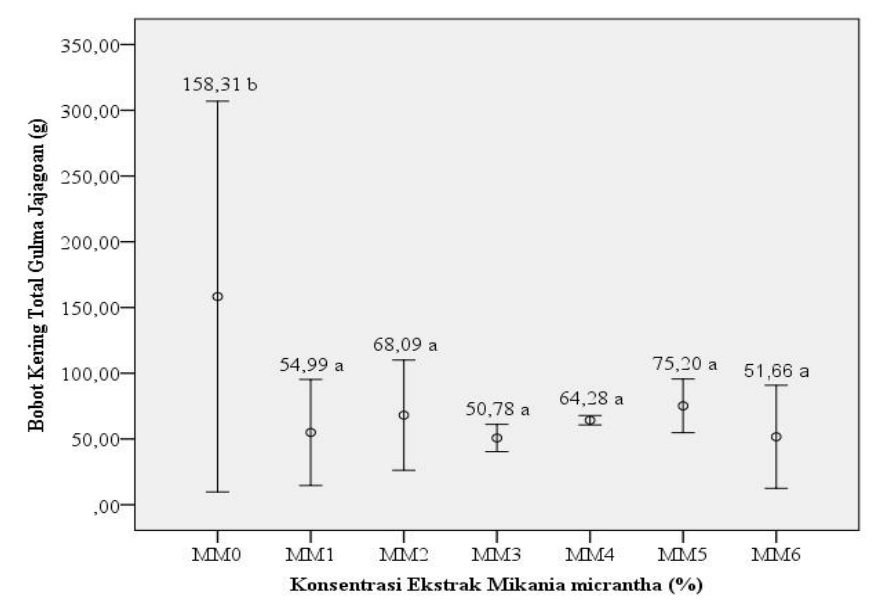

Gambar 4. Pengaruh konsentrasi ekstrak $M$. micrantha dan herbisida pembanding terhadap bobot kering total gulma jajagoan \pm SE. Konsentrasi ekstrak $(\mathrm{MMO}=0 \%$, MM1 $=20 \%$, MM2 $=40 \%$, MM3 $=60 \%$, MM4 $=80 \%$, MM5 $=100 \%$, dan MM6= herbisida 2,4-D dimetil amina

Tabel 5. Pengaruh konsentrasi ekstrak M. micrantha dan herbisida pembanding terhadap jumlah anakan gulma jajagoan umur 1-2 MSS

\begin{tabular}{lccc}
\hline \multirow{2}{*}{ Perlakuan } & \multicolumn{3}{c}{ Jumlah Anakan Gulma Jajagoan } \\
\cline { 2 - 4 } & Sebelum Semprot & $1 \mathrm{MSS}$ & $2 \mathrm{MSS}$ \\
\hline Konsentrasi Ekstrak 0\% & $8,93 \pm 0,56$ & $9,40 \pm 0,61 \mathrm{tn}$ & $10,47 \pm 0,76 \mathrm{~b}$ \\
Konsentrasi Ekstrak 20\% & $6,80 \pm 0,81$ & $7,00 \pm 0,77 \mathrm{tn}$ & $7,60 \pm 0,73 \mathrm{a}$ \\
Konsentrasi Ekstrak 40\% & $6,93 \pm 0,61$ & $8,47 \pm 0,41 \mathrm{tn}$ & $9,13 \pm 0,48 \mathrm{ab}$ \\
Konsentrasi Ekstrak 60\% & $7,00 \pm 0,65$ & $7,53 \pm 0,61 \mathrm{tn}$ & $8,00 \pm 0,66 \mathrm{ab}$ \\
Konsentrasi Ekstrak 80\% & $7,27 \pm 0,37$ & $8,87 \pm 0,53 \mathrm{tn}$ & $9,33 \pm 0,52 \mathrm{ab}$ \\
Konsentrasi Ekstrak 100\% & $6,47 \pm 0,20$ & $8,47 \pm 0,46 \mathrm{tn}$ & $6,67 \pm 0,52 \mathrm{a}$ \\
Herbisida 2,4-D Dimetil Amina & $8,07 \pm 0,68$ & $7,20 \pm 0,68 \mathrm{tn}$ & $6,60 \pm 0,73 \mathrm{a}$ \\
\hline
\end{tabular}

Keterangan: Data yang diikuti oleh huruf yang berbeda pada baris yang sama menunjukkan berbeda nyata berdasarkan uji DMRT $5 \% \pm$ SE. 
Indeks respons alelopati $M$. micrantha terhadap gulma jajagoan (E. crus-galli L.) dapat dilihat pada Gambar 5.

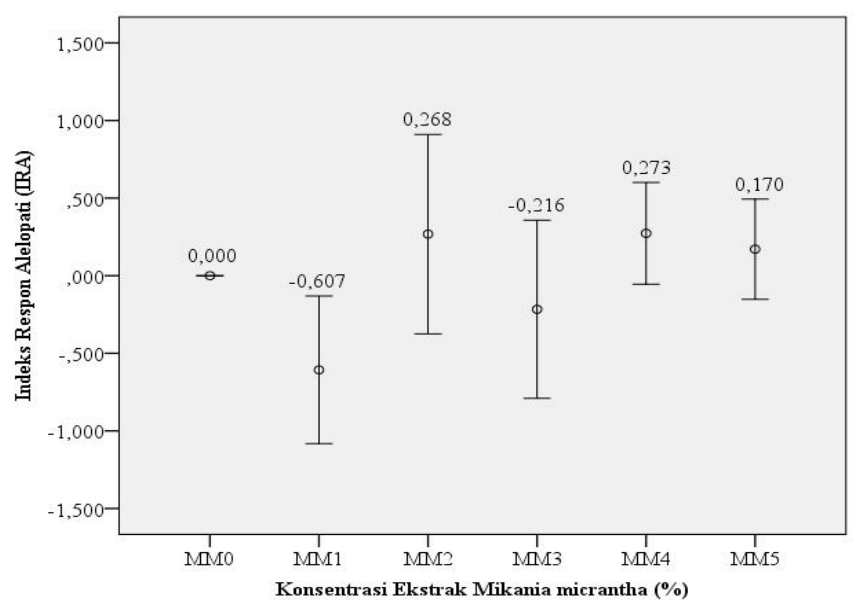

Gambar 5. Indeks respons alelopati M. micrantha terhadap gulma jajagoan (E. crus-galli L.) \pm SE. Konsentrasi ekstrak $\left(\mathrm{MM}_{0}=0 \%, \mathrm{MM}_{1}=20 \%, \mathrm{MM}_{2}=40 \%, \mathrm{MM}_{3}=60 \%, \mathrm{MM}_{4}=80 \%\right.$, dan $\mathrm{MM}_{5}=100 \%$ ).

Gambar 3 menunjukkan bahwa konsentrasi $20-100 \%$ ekstrak M. micrantha dan herbisida 2,4-D dimetil amina signifikan menekan bobot segar total gulma jajagoan dengan persentase penekanan tertinggi sebesar $65,91 \%$ terdapat pada konsentrasi $60 \%$ ekstrak dibandingkan kontrol.

Gambar 4 menunjukkan bahwa konsentrasi $20-100 \%$ ekstrak M. micrantha dan herbisida 2,4-D dimetil amina signifikan menekan bobot kering total gulma jajagoan dengan persentase penekanan tertinggi sebesar $67,92 \%$ terdapat pada konsentrasi $60 \%$ ekstrak dibandingkan kontrol.

Gambar 5 menunjukkan bahwa konsentrasi $20 \%$ dan $60 \%$ ekstrak $M$. micrantha dapat dikategorikan menghambat pertumbuhan biomassa gulma jajagoan dengan nilai indeks respons alelopati masing-masing sebesar $-0,607$ dan $-0,216$, sedangkan konsentrasi $40 \%$; $80 \%$ dan $100 \%$ bersifat stimulus bagi pertumbuhan biomassa gulma jajagoan.

\section{Dampak konsentrasi ekstrak Mikania micrantha dan herbisida pembanding terhadap karakteristik padi sawah}

Konsentrasi ekstrak $M$. micrantha dan herbisida pembanding signifikan meningkatkan jumlah anakan tanaman padi sawah, namun berpengaruh tidak nyata terhadap tinggi tanaman, bobot segar total, dan bobot kering total tanaman padi sawah. Ekstrak M. micrantha dengan konsentrasi $60 \%$ dapat meningkatkan jumlah anakan tanaman padi sawah tertinggi sebesar $57,23 \%$ dibandingkan kontrol. Ekstrak $M$. micrantha dengan konsentrasi $100 \%$ menunjukkan pertumbuhan tinggi tanaman padi sawah terendah diantara konsentrasi lainnya dan lebih pendek sebesar $15,11 \%$ dibandingkan kontrol. Konsentrasi $20 \%$ dan $80 \%$ ekstrak M. micrantha menunjukkan bobot segar total dan bobot kering total tanaman padi sawah tertinggi dibandingkan perlakuan lainnya.
Dengan demikian konsentrasi $20 \%, 60 \%$, dan $80 \%$ ekstrak $M$. micrantha masih dapat mendorong pertumbuhan jumlah anakan, bobot segar total dan bobot kering total tanaman padi sawah, namun kurang mendukung pada pertumbuhan tinggi tanaman. Hal ini disebabkan senyawa flavonoid yang terdapat pada gulma M. micrantha dapat menghambat pembelahan sel yang mengarah pada hambatan perpanjangan akar dan tajuk padi sawah. Kondisi ini mengakibatkan tanaman padi sawah membentuk jumlah anakan dan biomassa yang lebih tinggi sebagai mekanisme adaptasinya (Tabel 3-4). Menurut Rice (1984) hambatan yang disebabkan senyawa flavonoid dan fenol akan mengaktifkan enzim Indole Acetic Acid Oxidase dalam mengganggu fungsi auksin pada perpanjangan sel, sehingga pemanjangan sel tidak berlangsung dan berdampak terhambatnya tinggi tanaman. Ismail dan Chong (2002) melaporkan bahwa perkecambahan, panjang akar, dan bobot segar tanaman tomat dan pakcoy terhambat seiring dengan meningkatnya konsentrasi ekstrak $M$. micrantha sampai $50 \mathrm{~g} / \mathrm{l}$ air. Konsentrasi ekstrak M. micrantha $50 \mathrm{~g} / \mathrm{l}$ air signifikan menghambat perkecambahan tanaman tomat dan pakcoy masing-masing sebesar $94 \%$ dan $74 \%$ dibandingkan kontrol. Kong et al. (2007); Kong et al. (2008) melaporkan bahwa tanaman padi sawah merupakan salah satu penghasil flavonoid tergantung varietas, pada umumnya flavon glikosida terdegradasi di dalam tanah dan turunan aglikon bertindak sebagai antagonis mikroorganisme di rhizosfer. Jika transformasi ini berlanjut, maka flavonoid dengan mudah terdegradasi menjadi asam benzoat. Baral dan Maharjan (2011) melaporkan bahwa ekstrak $M$. micrantha dapat menghambat perpanjangan akar dan tajuk tanaman padi sawah, jagung, dan gandum. Sahu dan Devkota (2013) melaporkan bahwa semakin tinggi konsentrasi ekstrak M. micrantha sampai $10 \%$ maka perkecambahan padi sawah semakin rendah dengan rataan $83,34 \%$ dan dapat menghambat panjang akar dan tajuk tanaman padi sawah sampai $0,17 \mathrm{~cm}$ dan $0,12 \mathrm{~cm}$. Liu et al. (2016) juga melaporkan bahwa senyawa flavonoid dari gulma Avena fatua dapat mengganggu pertumbuhan gandum melalui penghambatan akar dan tajuk.

\section{Dampak konsentrasi ekstrak Mikania micrantha dan herbisida pembanding terhadap karakteristik gulma jajagoan}

Konsentrasi ekstrak M. micrantha dan herbisida pembanding signifikan menekan jumlah anakan umur 2 MSS, bobot segar total dan bobot kering total gulma jajagoan, namun berpengaruh tidak nyata terhadap jumlah anakan gulma jajagoan umur $1 \mathrm{MSS}$. Konsentrasi $20 \%$ dan $100 \%$ ekstrak $M$. micrantha serta herbisida 2,4D dimetil amina 1 l/ha signifikan menekan jumlah anakan gulma jajagoan masing-masing sebesar $27,41 \%$; $36,29 \%$; dan 36,96\% dibandingkan kontrol. Konsentrasi 20-100\% ekstrak M. micrantha dan herbisida 2,4-D dimetil amina signifikan menekan bobot segar total dan bobot kering total gulma jajagoan dengan persentase penekanan tertinggi terdapat pada konsentrasi $60 \%$ ekstrak M. micrantha masing-masing sebesar $65,91 \%$ 
dan $67,92 \%$ dibandingkan kontrol. Berdasarkan indeks respons alelopati, maka konsentrasi $20 \%$ dan $60 \%$ ekstrak $M$. micrantha dapat dikategorikan menghambat pertumbuhan biomassa gulma jajagoan (Gambar 5). Hal ini disebabkan senyawa flavonoid, tanin, dan alkaloid yang terdapat pada gulma $M$. micrantha dapat menekan pertumbuhan gulma jajagoan melalui gangguan aktivitas enzim di membran sel. Menurut Li dan Jin (2010) konsentrasi ekstrak akar $80 \mathrm{~g} / \mathrm{l}$ air, batang $400 \mathrm{~g} / \mathrm{l}$ air, dan daun $400 \mathrm{~g} / \mathrm{l}$ air dari $M$. micrantha signifikan menurunkan aktivitas enzim peroksidase (POD) pada bibit gulma Coix lacryma-jobi masing-masing menjadi $27 \%, 52 \%$, dan $34 \%$ dibandingkan kontrol. Ekstrak M. micrantha mampu menghambat perkecambahan dan pertumbuhan bibit Coix lacryma-jobi melalui pengaturan aktivitas antioksidase, seperti enzim (POD) dan katalase (CAT) di dalam sel. Penghambatan pertumbuhan bibit Coix lacryma-jobi berhubungan dengan kerusakan setelah teroksidasi di membran sel dengan peningkatan kandungan malondialdehida (MDA). Selain itu indeks respons pengaruh alelopati dari $M$. micrantha bernilai negatif atau tergolong menghambat dengan tingkat pengaruh alelopati tertinggi terdapat pada ekstrak batang, diikuti akar, dan daun. Kristanto (2006) melaporkan bahwa senyawa alelokimia fenol dan flavonoid lebih efektif menghambat aktivitas enzim perkecambahan. Shajib et al. (2012) melaporkan bahwa kandungan isoflavon dapat bertindak sebagai alelokimia yang bersifat fitotoksik terhadap spesies gulma monokotil maupun dikotil seperti E. crus-galli L. dan Amaranthus caudatus L. Anwar dan Hasibuan (2011) melaporkan bahwa konsentrasi ekstrak $10 \%$ gulma Imperata cylindrica dapat menghambat daya kecambah, panjang akar, panjang tajuk, bobot segar dan bobot kering gulma $E$. crus-galli masing-masing sebesar $91,57 \% ; 87,61 \% ; 92,97 \% ; 84,10 \%$ dan $53,27 \%$. Kholifah et al. (2018) melaporkan bahwa konsentrasi ekstrak daun Chromolaena odorata $200 \mathrm{~g} / \mathrm{l}$ dapat menghambat tinggi gulma dan panjang akar gulma $E$. crus-galli masing-masing sebesar $56,28 \%$ dan $46,90 \%$ pada 4 MSS. Grisi et al. (2012) melaporkan ekstrak daun Sapindus saponaria menggunakan aquades dapat menghambat perkecambahan dan perkembangan benih gulma E. crus-galli.

\section{KESIMPULAN}

Gulma M. micrantha memiliki metabolit sekunder alkaloid, flavonoid, dan tanin. Konsentrasi 20-100\% ekstrak M. micrantha terbukti menekan bobot segar total dan bobot kering total gulma jajagoan dengan persentase penekanan tertinggi terdapat pada konsentrasi $60 \%$ masing-masing sebesar $65,91 \%$ dan $67,92 \%$ dibandingkan kontrol. Indeks respons alelopati menunjukkan bahwa konsentrasi $20 \%$ dan $60 \%$ ekstrak M. micrantha dapat dikategorikan menghambat pertumbuhan biomassa gulma jajagoan. Konsentrasi $20 \%$, $60 \%$, dan $80 \%$ ekstrak $M$. micrantha memacu pertumbuhan jumlah anakan tanaman padi sawah.

\section{DAFTAR PUSTAKA}

Anwar R, Hasibuan I. 2011. Uji allelopati potensial terhadap perkecambahan gulma Echinochloa crussgalli (L.) Beauv. J Agroqua Media Inf Agron dan Budid Perair. 9(2):53-58.

Baral B, Maharjan BL. 2011. Antagonistic characteristics and phytochemical screening of invasive alien species of Nepal Himalaya. Int J Pharm Biol Arch. 2(5):1444-1450.

Clay SA, Kleinjan J, Clay DE, Forcella F, Batchelor W. 2005. Growth and fecundity of several weed species in corn and soybean. Agron J. 97(1):294-302. doi:doi.wiley.com/10.2134/agronj2005.0294a.

Dadang, Prijono D. 2011. Pengembangan teknologi formulasi insektisida nabati untuk pengendalian hama sayuran dalam upaya menghasilkan produk sayuran sehat. J IImu Pertan Indones. 16(2):100111.

Fernandes A, Maharani R, Sunarta S, Rayan R. 2018. Karakteristik kimia dan potensi daun tanaman akar bulou (Mikania micrantha Kunth) sebagai obat luka tradisional. J Penelit Ekosist Dipterokarpa. 4(2):109_ 116. doi:10.20886/jped.2018.4.2.109-116.

Gibson KD, Fischer AJ, Foin TC, Hill JE. 2002. Implications of delayed Echinochloa spp. germination and duration of competition for integrated weed management in water-seeded rice. Weed Res. 42(5):351-358. doi:10.1046/j.1365-3180.2002.00295.x.

Grisi PU, Ranal MA, Gualtieri SCJ, Santana DG. 2012. Allelopathic potential of Sapindus saponaria L. leaves in the control of weeds. Acta Sci Agron. 34(1):1-9. doi:10.4025/actasciagron.v34i1.11598.

Guntoro D, Chozin MA, Santosa E, Tjitrosemito S, Burhan AH. 2009. Kompetisi antara ekotipe echinochloa crus-galli pada beberapa tingkat populasi dengan padi sawah. J Agron Indones. 37(3):202-208.

Ismail BS, Chong T-V. 2002. Effects of aqueous extracts and decomposition of Mikania micrantha H.B.K. debris on selected agronomic crops. Weed Biol Manag. 2(1):31-38. doi:10.1046/j.1445-6664.2002.00045.x.

Jalaludin A, Yu Q, Powles SB. 2015. Multiple resistance across glufosinate, glyphosate, paraquat and ACCase-inhibiting herbicides in an Eleusine indica population. Weed Res. 55(1):82-89. doi:10.1111/wre.12118.

Junaedi A, Chozin MA, KIM KH. 2006. Perkembangan terkini kajian alelopati. HAYATI J Biosci. 13(2):79-84. doi:10.1016/S1978-3019(16)30386-2.

Kholifah N, Syaifudin EA, Sofian. 2018. Application of kirinyuh extracts (Chromolaena odorata (L.) R.M. King and H.E. Rob.) to germination and growth of jawan grass weed (Echinochloa cruss-galli). J Agroekoteknologi Trop Lembab. 1(1):67-76. doi:10.35941/jatl.1.1.2018.1504.67-76. 
Kong $\mathrm{CH}$, Wang P, Gu Y, Xu XH, Wang ML. 2008. Fate and impact on microorganisms of rice allelochemicals in paddy soil. J Agric Food Chem. 56(13):5043-5049. doi:10.1021/jf8004096.

Kong CH, Zhao H, Xu XH, Wang P, Gu Y. 2007. Activity and allelopathy of soil of flavone $\mathrm{O}$-glycosides from rice. J Agric Food Chem. 55(15):6007-6012. doi:10.1021/jf0703912.

Kristanto BA. 2006. Perubahan karakter tanaman jagung (Zea mays L.) akibat alelopati dan persaingan teki (Cyperus rotundus L.). J Pengemb Peternak Trop. 3(31):189-194.

Latha M, Jyothilakshmi M, Jyothis M. 2015. Antidermatophytic activity of Mikania micrantha Kunth: an invasive weed. Pharmacognosy Res. 7(5):20-25. doi:10.4103/0974-8490.157994.

Li J, Jin Z. 2010. Potential allelopathic effects of Mikania micrantha on the seed germination and seedling growth of Coix lacryma-jobi. Weed Biol Manag. 10(3):194-201. doi:10.1111/j.1445-6664.2010.00384.x.

Liu X, Tian F, Tian Y, Wu Y, Dong F, Xu J, Zheng Y. 2016. Isolation and identification of potential allelochemicals from aerial parts of Avena fatua L. and their allelopathic effect on wheat. J Agric Food Chem. 64(18):3492-3500. doi:10.1021/acs.jafc.5b05498.

Marambe B, Amarasinghe L. 2002. Propanil-resistant barnyardgrass [Echinochloa crus-galli (L.) Beauv.] in Sri Lanka: seedling growth under different temperatures and control. Weed Biol Manag. 2(4):194-199. doi:10.1046/j.1445-6664.2002.00068.x.

Pebriani, Linda R, Mukarlina. 2013. Potensi ekstrak daun sembung rambat (Mikania micrantha HBK) sebagai bioherbisida terhadap gulma maman ungu (Cleome rutidosperma DC) dan rumput bahia (Paspalum notatum Flugge). Protobiont. 2(2):32-38.

Perawati S, Andriani L, Pratiwi P. 2018. Aktivitas antibakteri ekstrak etanol daun sembung rambat (Mikania micrantha Kunth). Chempublish J. 3(2):4045. doi:10.22437/chp.v3i2.5554.

Pérez-Amador MC, Ocotero VM, Balcazar RI, Jiménez FG. 2010. Phytochemical and pharmacological studies on Mikania micrantha HBK (Asteraceae). Phyton Int J Exp Bot. 79:77-80.

Rice EL. 1984. Allelopathy. $2^{\text {nd }}$ ed. London: Academic Press, Inc.

Sahu A, Devkota A. 2013. Allelopathic effects of aqueous extract of leaves of Mikania Micrantha H.B.K. on seed germination and seedling growht of Oryza sativa L. and Raphanus sativus L. Sci World. 11(11):91-93. doi:10.3126/sw.v11i11.8559.
Saito K, Azoma K, Rodenburg J. 2010. Plant characteristics associated with weed competitiveness of rice under upland and lowland conditions in West Africa. F Crop Res. 116(3):308-317. doi:10.1016/j.fcr.2010.01.008.

Shajib MTI, Pedersen HA, Mortensen AG, Kudsk P, Fomsgaard IS. 2012. Phytotoxic effect, uptake, and transformation of biochanin a in selected weed species. J Agric Food Chem. 60(43):10715-10722. doi:10.1021/jf3023589.

Sunmonu TO, Van Staden J. 2014. Phytotoxicity evaluation of six fast-growing tree species in South Africa. South African J Bot. 90:101-106. doi:10.1016/j.sajb.2013.10.010.

Tampubolon K, Sihombing FN, Purba Z, Samosir STS, Karim S. 2018. Potensi metabolit sekunder gulma sebagai pestisida nabati di Indonesia. Kultivasi. 17(3):683-693. doi:10.24198/kultivasi.v17i3.18049.

Travlos IS, Economou G, Kanatas PJ. 2011. Corn and Barnyardgrass competition as influenced by relative time of weed emergence and corn hybrid. Agron J. 103(1):1-6. doi:10.2134/agronj2010.0245.

Umiyati U. 2019. Respon pertumbuhan gulma dan hasil tanaman jagung terhadap herbisida $276 \mathrm{~g} / \mathrm{l}$ pada sistem tanam TOT. Agrotechnology Res J. 3(1):1822. doi:10.20961/agrotechresj.v3i1.29248.

Usman, Purwoko BS, Syukur M, Guntoro DD. 2016. Toleransi galur harapan padi sawah (Oryza sativa L.) pada persaingan dengan gulma Echinochloa crusgalli. J Agron Indones. 44(2):111-118. doi:10.24831/jai.v44i2.13476.

Wei X, Huang H, Wu P, Cao H, Ye W. 2004. Phenolic constituents from Mikania micrantha. Biochem Syst Ecol. 32(11):1091-1096. doi:10.1016/j.bse.2004.04.013.

Williamson GB, Richardson D. 1988. Bioassays for allelopathy: Measuring treatment responses with independent controls. J Chem Ecol. 14(1):181-187. doi:10.1007/BF01022540.

Wilson MJ, Norsworthy JK, Scott RC, Gbur EE. 2014. Program approaches to control herbicide-resistant barnyardgrass (Echinochloa crus-galli) in Midsouthern United States rice. Weed Technol. 28(1):39-46. doi:10.1614/WT-D-13-00062.1.

Zhang M, Ling B, Kong C, Pang X, Liang G. 2003. Chemical components of volatile oil from Mikania micrantha and its biological activity on insects. J Appl Ecol. 14(1):93-96. 